\title{
SOCIAL CAPITAL, ABSORPTIVE CAPACITY AND ENTREPRENEURIAL BEHAVIOUR IN AN INTERNATIONAL CONTEXT
}

\author{
Ignacio Castro $^{1}$, Gabriel Cepeda ${ }^{2}$ \\ ${ }^{1,2}$ Department of Business Administration and Marketing, University of Seville, \\ ${ }^{1}$ Email: icastro@us.es \\ ${ }^{2}$ Email: gabi@us.es
}

\begin{abstract}
This study contributes to an understanding of the international growth of small and medium-sized enterprises. Thus, it proposes a learning-based model, which shows the influence that the social capital of the firm over external access and exploitation of knowledge and how this affects entrepreneurial orientation. This model is tested via structural equation modelling (Partial Least Squares) applied to a 178 Spanish international-firms sample. The results of data analysis emphasize, on the one hand, the importance of managing inter-organizational relationships in the firm learning processes and, on the other hand, how knowledge exploitation exerts a significant influence on the firm's entrepreneurial behaviour and, therefore, determines its international expansion.
\end{abstract}




\section{Introduction}

The international growth of firms will be determined by existing resources, represented by stocks of knowledge and capital (Prashantham and Young, 2011). Some researchers (Johanson and Vahlne, 2009; Johanson and Mattsson, 1988) pointed to the importance of cooperative agreements or strategic alliances as critical instruments in the international expansion of the firm. According to the network approach, focal actors through InterOrganizational Relationships (IORs) do have privileged access to knowledge about their partners (Johanson and Vahlne, 2009). Consequently, some researchers consider knowledge and social capital as some of the main determinants of the entrepreneurial internationalization speed (Oviatt and McDougall, 2005; Jones and Coviello, 2005).

Related to social capital, some researchers focus on the importance of networks in the firms' internationalization. Thus, their research shows how inter-organizational networks impact on medium-sized enterprises (SMEs) international expansion (Chetty and Blankenburg Holm, 2000; Coviello and Munro, 1997). In this sense, the internationalization process requires Absorptive Capacity (ACAP), which is an organizational capacity that encompasses this learning process (Cohen and Levinthal, 1990; Zahra and George, 2002). It makes reference to the firm capability to recognize the external knowledge value, acquire it and assimilate it within the firm context and transform it and exploit it. Accordingly, ACAP should facilitate firms to learn more from their alliance partners (Schildt et al., 2012), as their learning process will determine the potential usefulness of new knowledge generating new products, adopting new behaviour, and entering into new markets (Cohen and Levinthal, 1990). In this way, YliRenko et al. (2001) noted that in the internationalization literature, knowledge accessed and mobilized by focal firm through IORs plays a dual role: both the source of entrepreneurial behavior and encouraging international expansion.

Therefore, a deeper understanding of the processes by which social capital impacts on learning in the firm, facilitating the acquisition and exploitation of knowledge, and understanding the way in which this affects the entrepreneurial orientation (EO) of the focal actor, so as to increase its international expansion, is required. This social capital issue acquires special relevance in the SMEs internationalization process (Kenny and Fahy, 2011).

Taking into account previous insights and with the aim of covering this gap, the paper objective is to answer a central question: how does ACAP impact on the firm's EO and this in turn on its international expansion? In particular, we wish to understand how the firm social capital affects ACAP, centring on the acquisition and exploitation processes. Secondly, we analyse how both the former knowledge processes impacting on the firm's EO and then increasing its international expansion. This paper is organized as follows. We begin with a review of the literature about social capital and ACAP, in order to identify and measure the dimensions that make up the constructs, as well as their impact on EO and international expansion. We propose five hypotheses and develop an empirical study of a 178 SMEs sample. We then, present and discuss our results and conclude by examining their implications, its limitations and suggested future research lines.

\section{Theoretical Development}

Knowledge has been identified as one of the key resources in the behaviour and growth of firms (Penrose, 1959). Accordingly, some researchers point to the inter-organizational 


\section{Social Capital, Absorptive Capacity and Entrepreneurial Behaviour}

networks in which firms are embedded and, more specifically, social capital as a critical resource for the knowledge creation and transfer, as it stimulates cooperative behavior and minimizes opportunistic behavior (Nahapiet and Ghoshal, 1998; Yli-Renko et al., 2001).

In the knowledge-based view (KBV), learning is a fundamental concept to materialize knowledge as a competitive advantage. Accordingly, ACAP is a organizational capacity that attempts to incorporate this learning process into the firms (Cohen and Levinthal, 1990). Specifically, this element has been defined as "a capability pertaining to knowledge creation and utilization that enhances a firm's ability to gain and sustain a competitive advantage" (Zahra and George, 2002, p. 1852).

Accordingly, entrepreneurship has been defined as the process of discovery and exploitation of business opportunities (Shane and Venkataraman, 2000). This investigation will analyse organizational entrepreneurship as a strategic orientation that approaches organizational behaviour displaying innovativeness, risk-taking and proactivity (Covin and Slevin, 1991; Lumpkin and Dess, 1996). Therefore, some authors (Bojica et al., 2011) have noted that the acquisition and the use of knowledge impact significantly on the firm's EO and on its performance.

Finally, some researchers (Ripollés-Meliá et al., 2007) consider that firm international expansion is per se an entrepreneurial act, because it consists of identifying and exploiting new business opportunities in a new environment.

\subsection{Social capital and $A C A P$}

The literature on international entrepreneurship has principally used two criteria when analysing inter-organizational networks. A first criterion refers to whether external or internal ties are analysed (Adler and Kwon, 2002). Moreover, the first approach, known as bridging social capital, centres on the inter-organizational relations that the focal actor maintains with other actors such as competitors, clients, suppliers and other agents. The knowledge source in this case is external. Then, there is a second approach which has been called bonding social capital (Adler and Kwon, 2002) that analyses intraorganizational relations. Bonding social capital has principally been analysed in multinational companies (Tsai and Ghoshal, 1998). However, it is more difficult to analyse those factors in SMEs and it seems less relevant. Likewise, the most of investigations, studying the role of networks in the firms' internationalization, has been focused on SMEs (Coviello and Munro, 1997). Hence, we adopt bridging social capital, which stimulates cooperative activity facilitating access and mobilization of resources external to the organization such as knowledge (Yli-Renko et al., 2001). The second element is relational embeddedness, which refers to the strength of the link, and is assessed through the frequency of interaction between partners and their level of resource commitment to the relationship (Prashantham and Young, 2011). In accordance with Granovetter's idea of weak versus strong ties, Blyler and Coff (2003) pointed out that social capital allows firms to acquire, to integrate, to recombine, and to release resources. Previous studies have observed that when two actors interact over time, their relationships become stronger and the actors are more likely to view each other as trustworthy (Tsai and Ghoshal, 1998). On this point, various researchers (Gulati, 1995) have suggested that trust is the critical factor in the creation and transfer of knowledge and other resources. 
Castro and Cepeda

Prashantham and Young (2011) combine both criteria to propose how the different types of social capital are related to ACAP (see Table 1). Accordingly, ACAP is made up of four dimensions that are: acquisition, assimilation, transformation, and exploitation. In this work we focus on the one hand on acquisition which refers to "a firm' capability to identify and acquire externally generated knowledge that is critical to its operations" (Zahra and George, 2002: 189); and on the other hand on exploitation that is a firm's capability "based on the routines that allow firms to refine, extend, and leverage existing competencies or to create new ones by incorporating acquired and transformed knowledge into its operations" (Zahra and George, 2002: 190). In conclusion, ACAP is a crucial pool of processes related to the creation and usage of knowledge that allows the firm to set and to maintain its competitiveness.

Insert Table 1 about here

\subsection{Knowledge Acquisition and weak ties}

Zahra and George (2002) considered that bridging social capital is a critical antecedent of ACAP. Blyler and Coff (2003) pointed out that bridging social capital facilitates the acquisition of resources by promoting a constant information flow from diverse sources. Accordingly, to the extent that the network in which the focal actor is immersed is made up of weak ties, it can access and mobilize various, new information sources (Oviatt and McDougall, 2005). In conclusion, weak bridging ties mean that the focal actor can access and acquire a broad range of novel knowledge (Granovetter, 1985) that may be useful for its learning potential (Zahra et al., 2000). Along these same lines, Rowley et al. (2000: 371 ) considered that "weak ties are more likely than strong ties to be local bridges to distant others possessing unique information". Thus, these authors considered that acquisition is a process that attempts to increase the organizational knowledge stock, and it may be categorized as exploration (March, 1991). In accordance with these ideas, we state that:

\section{H1: Weak bridging social capital is positively associated to knowledge acquisition.}

\subsection{Knowledge Exploitation and strong ties}

The focal firm develops relations with actors that could play a relevant role in the knowledge exploitation in international markets (Prashantham and Young, 2011). Unlike the earlier one, this process is tied to the exploitation category. Some researchers point out that optimal knowledge exploitation requires strong ties, as do other types of resources which the actor can access through relations (Rowley et al., 2000). According to Prashantham and Young (2011), the strong links are especially relevant in the exploitation context. Finally, Tsai and Ghoshal (1998) affirmed that the exchange and the combination of resources emerged, insofar as strong links existed between partners. In conclusion, the focal actor may exploit knowledge to a greater extent and more swiftly through strong bridging social capital than if it were done individually. Accordingly:

H2: Strong bridging social capital is positively associated to the accelerated knowledge exploitation.

\subsection{ACAP and EO}




\subsubsection{Knowledge Acquisition and EO}

The concept of ACAP (Cohen and Levinthal, 1990) refers in a more direct way to the difference between accessing a resource and its exploitation. This capacity, despite its four dimensions that are complementary and interdependent, may be analysed in an isolated way to examine in greater depth how each one of these affect EO and, in consequence the firm international expansion, insofar as they relate to the competitive advantage creation. In this study, knowledge exploration will be analysed through the dimension 'Knowledge Acquisition' and, its use or exploitation, through the 'Knowledge Exploitation' dimension.

The EO has been defined by some authors as the processes, practices and decisionmaking activities that lead to new entry (Lumpkin and Dess, 1996). The majority of researchers consider that this concept is made up of three fundamental dimensions, which are: innovativeness, risk-taking and proactivity (Covin and Slevin, 1991). Therefore, firms with innovativeness, proactivity and risk-taking high levels tend to a greater extent to discover and to exploit new entrepreneurial opportunities at both a product level and a market level (Bojica et al., 2011).

'Knowledge Acquisition' is considered a key determinant by some researchers in the firm entrepreneurial behaviour (Bojica et al., 2011). In this sense, access to novel knowledge is critical for the discovery and exploitation of entrepreneurial opportunities (Shane and Venkataraman, 2000). Therefore, firms use IORs with their partners to access and to accumulate knowledge, and that knowledge stock constitutes the framework for the EO of the focal actor (Yli-Renko et al., 2001). Without this knowledge, firms are less able to discover and to exploit new opportunities, so the firm international expansion will not be as great as it would be otherwise (Wiklund and Shepherd, 2003). Thus:

\section{H3: Knowledge acquisition is positively associated to EO.}

\subsubsection{Knowledge Exploitation and EO}

Even though the focal actor access to novel knowledge may support its EO, we consider that knowledge mobilization through the focal actor's strong bridging social capital and its combination will allow it to develop innovative proposals in terms of products and geographic markets and, therefore, to influence the firm's EO more significantly. These ideas may be found in the entrepreneurship and innovation literature (Bojica et al., 2011). Accordingly, Covin and Slevin (1991) stated that entrepreneurial behaviour not only requires access to, but also a large volume of resources mobilization. Only with great difficulty would the focal actor and, in particular, the SMEs, have access at any time to these resources. Thus, the knowledge exploitation should positively support its entrepreneurial behaviour (Wiklund and Shepherd, 2003). Based on this logic and previous research, we hypothesise as follows:

\section{H4: Knowledge Exploitation is positively associated to EO.}

\subsection{EO and international expansion}

Covin and Slevin (1991) defined entrepreneurial firms as those organizations whose principal strategic objectives are innovation and growth. Furthermore, Ripollés-Meliá et al. (2007) posited an evident relation between the firm's EO and its growth objective. Accordingly, the firms internationalization process implies that the focal actor will develop its activity outside of the domestic market in foreign countries. This requires an 


\section{Castro and Cepeda}

entrepreneurial behavior, as the firm has to identify and exploit new business opportunities in a new environment (Ripollés-Meliá et al., 2007). Finally, Wales et al. (2012) point out that EO strategic posture is that firms are likely to embrace the creation and pursuit of new entries. Therefore, firms will be more capable of meeting the resource requirements of EO, on the basis of their IORs, which will positively influence their international expansion. In conclusion, the focal-actor international-growth depends to a great extent on its EO; in other words, it depends on the innovative and proactive attitude of the focal actor, as well as the actor ability to assume the risk involved in the development of activities in unknown competitive environments. In view of this reasoning, we propose that:

\section{H5: EO is positively associated to international expansion.}

Insert Figure 1 about here

\section{Methodology}

\subsection{Sample}

The sample was selected from the Spanish exporters and importers directory, which uses information provided by Public Finance. We selected firms from five different industries, characterized by a high proportion of exporters (Chemicals, Food and Beverages, Textiles, Manufacturing and Commerce). The total population comprised 3,158 firms, of which about $50 \%$ were exporters. Questionnaires were sent to 1,524 firms. We obtained 200 valid responses $(15.35 \%$ of 1,303$)$ through interviews. As explained in theoretical development section, we centre on SMEs. For this reason, all those firms with over 250 employees were filtered out, leaving a final sample of 178 firms.

\subsection{Variables}

International expansion was gauged by means of a perceptual measure. A survey asked participants to evaluate geographic expansion in the international market over the past 5 years (INTER_EXPANSION).

Firm's Entrepreneurial Orientation: The EO dimensions (innovativeness, risk taking and proactiveness) were measured using a scale developed by Lumpkin (1998) based on the scales developed and tested for reliability by Covin and Slevin (1991) (see Annex).

Following these study objectives, we modelled EO as a second-order formative construct. Bridging Social Capital: two networks were analysed for each focal actor to approximate this concept measurement: personal egocentric social network and inter-organizational networks.

Personal (egocentric) social networks: the position generator method was used, because it is an accurate tool for it (Batjargal, 2003). A table with 9 types of occupations were developed. These 9 positions were identified by a group of experts through a Delphi method (see Annex).

Inter-organizational networks: a 5 items scale was used to measure the quality and strength of the links. As in the previous case, a Delphi method was used too. Particularly, participants were asked about their membership of the networks as are presented in Annex. 
To measure the links quality and strength, the respondents had to indicate the relationships intensity for each of the 9 occupations (where 7 is very strong and 1 very low). On the basis of earlier data, the following indicators were constructed: on the one hand, strong ties (STRONGPOS) and weak ties (WEAKPOS) in the egocentric network of the positions of the focal actor; and, on the other hand, strong ties (STRONGNET) and weak ties (WEAKNET) in their inter-organizational networks. These indicators have been developed to measure strong bridging social capital (STRONG_BSCAP) and weak bridging social capital (WEAK_BSCAP).

$A C A P$ : we used two different scales, one for each ACAP dimension under analysis: Knowledge Acquisition and Knowledge Exploitation proposed by Jansen et al. (2005).

\subsection{Analysis}

Smart PLS 2.0 (Ringle et al., 2005) was used in the study. We adopted the latent model perspective to analyse the relationships between the different constructs and their indicators. Four model constructs were operationalized as reflective, while one of them 'EO'- was modelled as a second-order formative construct.

With regard to the measurement model, we began by assessing the individual item reliability (Table 2). The indicators were above the accepted threshold of 0.707 for each factor loading (Carmines and Zeller, 1979) .

\section{Insert Table 2 about here}

From an examination of the results shown in Table 2, we can state that all of the constructs are reliable. Their Cronbach's alpha coefficients are good and they have a composite reliability of over 0.7 (Nunnally, 1978). The AVE should be greater than 0.5, such that it accounts for at least $50 \%$ of the variance of the indicators (Fornell and Larcker, 1981). All the constructs of our model meet this condition. For discriminant validity, we compared the square root of the AVE (i.e., the diagonals in Table 3) with the correlations between constructs (i.e., the non-diagonal elements in Table 3). On average, each construct related more strongly to its own measures than to others.

Insert Table 3 about here

The evaluation of the formative dimensions of the high-order construct, 'EO' differed from that of the reflective dimensions. The concern with formative dimensions is potential multicolinearity with overlapping dimensions, which could produce unstable estimates. The collinearity test results show the Variance Inflation Factor (VIF) scores of the second-order construct for its dimensions are far below the commonly accepted cutoff of 3.3. In addition, we confirmed the validity of the formative dimensions using the procedures suggested by Fornell and Larcker (1981).

\subsection{Results}

The structural model results are summarised in Table 4 . As can be seen, all the hypothesized relationships are significant, and therefore, all the hypotheses are supported except $H 3$. The structural model is evaluated by examining the $R^{2}$ values and the size of the structural path coefficients. 


\section{Castro and Cepeda}

The stability of the estimates is examined by using the t-statistics obtained from a bootstrap test with 5000 resamples. Table 4 sets out the model statistics, the path coefficients and the $t$ values observed with the level of significance achieved from the bootstrap test.

Insert Table 4 about here

\section{Discussion and Conclusions}

Our study has shown the role that social capital plays as an antecedent of some dimensions of ACAP and how it impacts on the firm entrepreneurial behaviour, stimulating its international expansion. In this research, we have proposed a model in which bridging social capital (Prashantham and Young, 2011) and some ACAP dimensions (Zahra and George, 2002) are combined with EO in order to explain the firm's international expansion. Five hypotheses have been advanced.

The hypothesis $\mathrm{H} 1$ proposed the positive influence of weak bridging social capital on Knowledge Acquisition. The results reported confirm H1. Thus, weak bridging social capital supports the knowledge acquisition, or in other words, the exploration process. This is in line with the literature, as exploration focuses on new knowledge (Rowley et al., 2000).

$\mathrm{H} 2$ proposed a positive association between strong bridging social and Knowledge Exploitation. The results obtained show that this relationship is positive and significant. Accordingly, strong bridging social capital involves greater frequency of interactions and resource commitment, which will give the focal actor valuable access to knowledge and other resources as they are mobilized (Granovetter, 1985).

Next, the results find no evidence to support the affirmation in $\mathrm{H} 3$ that Knowledge Acquisition is positively associated with EO. This may be justified by the fact that mere access to novel knowledge is necessary, but not sufficient to provoke the firm entrepreneurial behaviour that will promote and increase its international expansion (Kotabe et al., 2011).

In relation to $\mathrm{H} 4$, the results have shown that knowledge exploitation influences significantly the firm's EO. Hence, Parmigiani and Rivera-Santos (2011: 1123) defined the IORs exploitation as "a strategically important, cooperative relationship to execute existing knowledge, tasks, functions or activities". Therefore, taking into account the phenomenon under analysis, which is the firm international expansion, it is exploitation that really increases the firm's EO, increasing the probability that the firm will identify and take advantage of commercial opportunities and will penetrate new markets.

Fifth, H5 has proposed that the firm EO will have a positive influence on its international expansion. Thus, as the results of the complete model have shown, it is the knowledge exploitation and not exploration that is what significantly influences the firm entrepreneurial behaviour, increasing its international expansion. This supports some researchers statements (Parmigiani and Rivera-Santos, 2011), in that the key activity of exploitation is the firm expansion. Thus, insofar as the firm through its IORs can 
mobilize the necessary resources, this will reinforce the firm entrepreneurial behaviour oriented towards the new markets penetration.

In conclusion, these results have contributed to both IORs and on internationalisation and learning literature, showing weak bridging and strong bridging capital as different types of social capital. Thus, it is knowledge exploitation, which significantly influences the firm's EO and increasing the firm international expansion as well.

The study's managerial implications helps managers to be able to recognize that future market opportunities emanate largely from IORs.

This research is not exempt of limitations. A first limitation is that the firm sample analysed belongs to one country (Spain) and one firm type (established SMEs), which could create certain drawbacks by generalizing and extrapolating the results. Secondly, the study has been defined as a cross-sectional. Therefore, performing a longitudinal study among other types of international firms, international new ventures or Multinational Enterprises, or analysing different groups of firms with different characteristics such as high-tech SMEs, would constitute interesting future research lines.

\section{References}

Adler, P.S. and Kwon, S. (2002) 'Social capital: Prospects for a new concept', Academy of Management Review, Vol. 27, pp.17.

Autio, E., Sapienza, H.J. and Almeida, J.G. (2000) 'Effects of Age at Entry, Knowledge Intensity, and Imitability on International Growth', Academy of Management Journal, Vol. 43, pp.909-924.

Batjargal, B. (2003) 'Social capital and entrepreneurial performance in Russia: A longitudinal study', Organization Studies, Vol. 24, pp.535-556.

Blyler, M. and Coff, R.W. (2003) 'Dynamic capabilities, social capital, and rent appropriation: ties that split pies', Strategic Management Journal, Vol. 24, pp.677686.

Bojica, A.M., Fuentes, M.d.M. and Gómez-Gras, J.M. (2011) 'Radical and incremental entrepreneurial orientation: The effect of knowledge acquisition', Journal of Management and Organization, Vol. 17, pp.326-343.

Carmines, E.G. and Zeller, R.A. (1979) 'Reliability and Validity Assessment' Sage University Paper Series on Quantitative Applications in the Social Sciences, Beverly Hills and London.

Chetty, S. and Blankenburg Holm, D. (2000) 'Internationalisation of small to mediumsized manufacturing firms: a network approach', International Business Review, Vol. 9, pp.77-93.

Cohen, W.M. and Levinthal, D.A. (1990) 'Absorptive Capacity: A New Perspective On Learning And Innovation', Administrative Science Quarterly, Vol. 35, pp.128-152.

Coviello, N.E. and Munro, H.J. (1995) 'Growing the entrepreneurial firm: Networking for international market development', European Journal of Marketing, Vol. 29, pp.49.

Coviello, N. and Munro, H. (1997) 'Network Relationships and the Internationalisation Process of Small Software Firms', International Business Review, Vol. 6, pp.361386.

Covin, J.G. and Slevin, D.P. (1991) 'A Conceptual Model of Entrepreneurship As Firm Behavior', Entrepreneurship Theory and Practice, Vol. 16, pp.7. 
Fornell, C. and Larcker, D.F. (1981) 'Evaluating structural equation models with unobservable variables and measurement error', Journal of Marketing Research, Vol. 18, pp.39-50.

Granovetter, M. (1985) 'Economic Action and Social Structure: The Problem of Embeddedness', The American Journal of Sociology, Vol. 91, pp.481-510.

Gulati, R. (1995) 'Does familiarity breed trust? The implications of repeated ties for contractual choice in alliances', Academy of Management Journal, Vol. 38, pp.85112.

Johanson, J. and Mattsson, L. (1988) 'Internationalization in industrial systems - a network approach'in , in N. Hood and J.E. Vahlne (Eds.), Strategies in Global Competition, Croom Helm, New York, pp.287-314.

Johanson, J. and Vahlne, J. (2009) 'The Uppsala internationalization process model revisited: From liability of foreignness to liability of outsidership', Journal of International Business Studies, Vol. 40, pp.1411-1431.

Jones, M.V. and Coviello, N.E. (2005) 'Internationalisation: conceptualising an entrepreneurial process of behaviour in time', Journal of International Business Studies, Vol. 36, pp.284-303.

Kenny, B. and Fahy, J. (2011) 'Network resources and international performance of high tech SMEs', Journal of Small Business and Enterprise Development, Vol. 18, pp.529-555.

Lumpkin, G.T. and Dess, G.G. (1996) 'Clarifying the entrepreneurial orientation construct and linking it to performance', The Academy of Management Review, Vol. 21, pp.135-172.

March, J.G. (1991) 'Exploration and Exploitation in Organizational Learning', Organization Science, Vol. 2, pp.71-87.

Nahapiet, J. and Ghoshal, S. (1998) 'Social capital, intellectual capital, and the organizational advantage', Academy of Management Review, Vol. 23, pp.242-266.

Nunnally, J.C. (1978) Psychometric Theory, McGraw-Hill, New York.

Oviatt, B.M. and McDougall, P.P. (2005) 'Defining International Entrepreneurship and Modeling the Speed of Internationalization', Entrepreneurship Theory and Practice, Vol. 29, pp.537-553.

Parmigiani, A. and Rivera-Santos, M. (2011) 'Clearing a Path Through the Forest: A Meta-Review of Interorganizational Relationships', Journal of Management, Vol. 37, pp.1108-1136.

Penrose, E. (1959) The Theory of the Growth of the Firm, Wiley, New York.

Prashantham, S. and Young, S. (2011) 'Post-Entry Speed of International New Ventures', Entrepreneurship Theory and Practice, Vol. 35, pp.275-292.

Ringle, C.M., Wende, S. and Will, A. (2005): SmartPLS 2.0 (Beta), University of Hamburg, Hamburg, Germany.

Ripollés-Meliá, M., Menguzzato-Boulard, M. and Sánchez-Peinado, L. (2007) 'Entrepreneurial orientation and international commitment', Journal of International Entrepreneurship, Vol. 5, pp.65-83.

Rowley, T., Behrens, D., and Krackhardt, D. (2000). Redundant governance structures: An analysis of structural and relational embeddedness in the steel and semiconductor industries, Strategic Management Journal, 21(3), 369.

Schildt, H., Keil, T. and Maula, M. (2012) 'The temporal effects of relative and firm-level absorptive capacity on interorganizational learning', Strategic Management Journal, Vol. 33, pp.1154. 
Shane, S. and Venkataraman, S. (2000) 'The promise of entrepreneurship as a field of research', Academy of Management. The Academy of Management Review, Vol. 25, pp.217-226.

Tsai, W. and Ghoshal, S. (1998) 'Social capital and value creation: The role of intrafirm networks', Academy of Management Journal, Vol. 41, pp.464.

Wiklund, J. and Shepherd, D. (2003) 'Knowledge-based resources, entrepreneurial orientation, and the performance of small and medium-sized businesses', Strategic Management Journal, Vol. 24, pp.1307.

Yli-Renko, H., Autio, E. and Sapienza, H.J. (2001) 'Social capital, knowledge acquisitions, and knowledge exploitation in young technology-based firms', Strategic Management Journal, Vol. 22, pp.587.

Zahra, S.A., Ireland, R.D. and Hitt, M.A. (2000) 'International expansion by new venture firms: International diversity, mode of market entry, technological learning, and performance', Academy of Management Journal, Vol. 43, pp.925-950.

Zahra, S.A. and George, G. (2002) 'Absorptive capacity: A review, reconceptualization, and extension', Academy of Management Review, Vol. 27, pp.185. 